\title{
The Incremental Militarization of Outer Space: A Threshold Analysis
}

\author{
Francis Grimal* and Jae Sundaram**
}

\begin{abstract}
The overarching theme of this article is not to revisit existing debates surrounding the application of jus ad bellum or jus in bello parameters to the "peculiarities" of outer space. Rather, this article examines the major treaties that regulate a States' military activities in outer space (including, for example, the Outer Space Treaty, Limited Test Ban Treaty, Liability Convention and, PPWT), alongside Charter norms, such as Article 2(4) of the UN Charter, to pinpoint the threshold of breach, violation and incremental militarization of outer space. With respect to the PPWT, it is important to note at this juncture that it remains a "proposal", and at best, lex ferenda. A natural consequence from this analysis will be to underscore the extent to which "toleration" of such violations by States, and the international community as a whole, has resulted in the incremental militarization of space.
\end{abstract}

I feel that in the future whoever has the capability to control space will likewise possess the capability to control the surface of the earth. - General Thomas D. White, USAF Chief of Staff, 29 November 1957.

\section{Introduction}

1. Academic debate surrounding the ever-increasing militarization of outer space within the overall context of the jus ad bellum, has been somewhat overshadowed (at least in more recent times) by more prominent scrutiny over the lawfulness of

\footnotetext{
* University of Buckingham, UK. francis.grimal@buckingham.ac.uk.

** University of Buckingham, UK. jae.sundaram@buckingham.ac.uk. The authors would like to express their sincerest thanks to Professor Jinyuan $\mathrm{Su}$ for all his invaluable comments and feedback on an earlier draft.
} 
"activities" within the fifth dimension (the cyber realm). ${ }^{1}$ Relatively little existing literature considers the specifics of thresholds of militarization of outer space, and is predominantly concerned with transposing the existing tapestry of the jus ad bellum, and the jus in bello to outer space. ${ }^{2}$

1 Simply on the former (cyber-warfare), in the last couple of years alone, see, for example, Francis Grimal and Jae Sundaram, Cyberwarfare and Autonomous SelfDefence, 4 Journal on the Use of Force and International Law (2017), 312; James A. Green, The Use of Cyber Force: Regulation under the Jus ad Bellum, in: James A. Green (ed.) , Cyber Warfare: A Multidisciplinary Approach (2015), who notes the following works: Marco Benatar, The Use of Cyber Force: Need for a Legal Justification?, 1 Goettingen JIL (2009), 375; Russell Buchan, Cyber Attacks: Unlawful Uses of Force or Prohibited Interventions, 17 Journal of Conflict and Security Law (JCSL) (2012), 212; Yoram Dinstein, The Principle of Distinction and Cyber War in International Armed Conflicts, 17 JCSL (2012), 261; Oona Hathaway, Rebecca Crootof, Philip Levitz, Haley Nix, Aileen Nowlan, William Perdue and Julia Spiegel, The Law of Cyber-Attack, 100 California Law Review (2012), 817; Erki Kodar, Computer Network Attacks in the Grey Areas of Jus ad Bellum and Jus in Bello, 9 Baltic Yearbook of International Law (2009), 133; Michael N. Schmitt, Cyber Operations and the Jus in Bello: Key Issues, 87 International Law Studies (2011), 113; David Turns, Cyber Warfare and the Notion of Direct Participation in Hostilities, 17 JCSL (2012), 279; Sean Watts, Combatant Status and Computer Network Attack, 50 Virginia JIL (2010), 391; and Matthew C. Waxman, Cyber-Attacks and the Use of Force: Back to the Future of Article 2(4), 36 Yale JIL (2011), 421.

2 Compared with both cyber-warfare and "drones", there exists perhaps a relative paucity of contemporary literature on the "use of force in outer space," although there are several dedicated journals to the corpus of space law, e.g., The Journal of Space Law; The Annals of Air and Space Law; Air \& Space Law; and German Journal of Air and Space Law (ZLW) as well as the annual International Institute of Space Law (IISL) Proceedings. Recent scholarly articles are limited to the following: Michel Bourbonniere, Law of Armed Conflict (LOAC) and the Neutralisation of Satellites or Jus in Bello in Satellites, 9 JCSL (2004), 43; Michael N. Schmitt, International Law and Military Operations in Space, Max Planck Yearbook of United Nations Law: Volume 10 (2006), 89-125; Michel Bourbonniere, Balancing Space Law and the Law of Armed Conflict, 18 EJIL (2007), 873; Arjen Vermeer, A Legal Exploration of Force Application in Outer Space, 46 Military Law \& Law of War Review (2007), 299, 317-8; Jackson Maogoto and Steven Freeland, The Final Frontier: The Laws of Armed Conflict and Space Warfare, 23 Connecticut JIL (2007), 165-195; Tare C. Brisibe, Customary International Law, Arms Control and the Environment in Outer Space, 8 Chinese JIL (2009), 375-393; Zachos A. Paliouras, The Non-Appropriation Principle: The Grundnorm of International Space Law, 27 Leiden JIL (2014), 37-54; Blair S. Kuplic, The Weaponization of Outer Space: Preventing an Extraterrestrial Arms Race, 39 North Carolina Journal of International Law \& Commercial Regulation (2014), 1123; Fabio Tronchetti, The Right of Self-Defence in Outer Space: An Appraisal, 63 German Journal of Air and Space Law (2014), 92. 
The increase in the number of space actors with launch capabilities from two to eleven $^{3}$ (approximately sixty States owning and operating active satellites in space), ${ }^{4}$ means outer space must already be viewed as another potential "battlefield". Such proliferation in activity in outer space-both research and military, suggests a human "colonization" of outer space in recent times. ${ }^{5}$

2. In the context of militarization, early space exploration emerged largely as a result of military advancement in the post-WWII era. ${ }^{6}$ These technological advances made in the political context of the "cold war" necessitated developing international conventions, which, endeavoured to avoid direct confrontation in "space". 7 The second half of the twentieth century saw the former Soviet Union, in 1957, launch its first artificial satellite, Sputnik $I,{ }^{8}$ leading to the Soviet Union

3 Jinyuan Su, Space Arms Control: Lex Lata and Currently Active Proposals, Asian JIL (2015), 1. The author identifies the key players as Russia, United States (US), France, Japan, China (PRC), United Kingdom (UK), the European Space Agency (ESA), India, Israel, Ukraine, Iran, and DPRK (North Korea).

4 US Department of Defence and US Office of the Director of National Intelligence, National Security Strategy: Unclassified Summary (January 2011) (www.dni.gov/ files/documents/Newsroom/Reports\%20and\%20Pubs/2011_nationalsecurityspaces trategy.pdf), accessed on 29 January 2018.

5 For example, Chris Hadfield, the first Canadian astronaut to walk in space, made the comment on air in an interview broadcast on 7 October 2016, BBC Radio 4, that "[...] we started colonising space sixteen years ago." Hadfield was obviously referring to the turn of the century, when activities carried out by developed countries with increased space capabilities resulted in space stations with research facilities being parked in outer space.

6 James C. Moltz, Crowded Orbits: Conflicts and Cooperation in Space (2014), 12, 16. The author notes how both the US and the Soviet Union, in the aftermath of the defeat of the Nazis, captured the surrendered German military scientists, their blueprints, and hardware to jumpstart their own missile programmes, to successfully bring space activity within their respective reaches. For instances, German engineer Wernher von Braun, who used Nazi funding to develop the first rockets to pass the edges of the atmosphere, later worked for the US military and developed the Redstone intermediate-range missile, and the Jupiter C rocket which could pass through space. See also Dave Webb, Space Weapons: Dream, Nightmare or Reality?, in: Natalie Bormann and Michael Sheehan (eds.), Securing Outer Space (2009), 24-25. The author notes that through "Operation Paperclip" the Nazi origins of the scientists and engineers were obscured, allowing them to work in the US.

7 See generally Stephan Hobe, Space Law-An Analysis of Its Development and Its Future, in: Christian Brünner and Alexander Soucek (eds.), Outer Space in Society, Politics, and Law, Studies in Space Policy, Vol 8 (2012), 476-489.

8 On 4 October 1957, the Soviet Union launched Sputnik I, the first artificial satellite, into an elliptical low Earth orbit. Sputnik I was the size of a beach ball $(58 \mathrm{~cm}$ or 22.8 inches in diameter) and took 98 minutes to orbit the Earth on an elliptical path. This launch marked the start of the space age and ushered in new political, military, technological, and scientific developments. The Soviet Union followed the 
and the United States battling for hegemony in "space" exploitation. Recent decades have witnessed ever-increasing activity by States, prompting the not-sounreasonable conclusion that space is being weaponized. Consequently, laws enacted in the twentieth century were primarily designed to regulate the actions of States and non-State operations within the Earth's realm, i.e., Earth comprising of land, water and air/atmosphere.

3. The key legal instruments relating to the use of outer space are primarily contained in the Outer Space Treaty 1967, the Rescue and Return Treaty 1968, the Liability Convention 1972, the Registration Convention 1976, and the Moon Agreement 1979. ${ }^{9}$ In addition to these legal instruments, several non-binding instruments were created in the latter part of the twentieth Century ${ }^{10}$ (including debris mitigation guidelines) resulting from UN General Assembly Resolutions. ${ }^{11}$ It is also worth including here the review of the UN space laws carried out by the United Nations Committee on the Peaceful Uses of Outer Space (UNCOPUOS). ${ }^{12}$ The Committee highlighted two issues for discussion, viz., the concept of "launch State," and the registration of space objects. ${ }^{13}$

Sputnik I with the launch of Sputnik II on 3 November 1957. Sputnik II had a much heavier payload, including a dog named Laika. See, Sputnik and The Dawn of the Space Age, NASA (10 October 2007) (http://history.nasa.gov/sputnik/), accessed on 29 January 2018.

9 Hobe, above n.7. Hobe also observes that with the adoption of this Agreement in 1979, the first phase of space law-making ended. Interestingly, so far, no space power has come forward to ratify the Moon Agreement. Compared to other Treaties, the Moon Agreement has relatively few signatories.

10 UN General Assembly Resolution on the Legal Principles Governing the Activities of States in the Exploration and Use of Outer Space 1962 (XIII), Resolution 41/65 on Remote Sensing of the Earth from Outer Space, Resolution 47/68 on Principles Relevant to the Use of Nuclear Power Sources (NPC) in Space, Resolution 37/92 on Direct Broadcasting by Satellite, Resolution 51/112 on Space Benefits.

11 Whether the UN resolutions have the same force of law as international Conventions will have to be considered in any given situation where actions carried out in outer space are scrutinised.

12 The United Nations Committee on the Peaceful Uses of Outer Space (UNCOPUOS) was founded in 1958 through UN General Assembly Resolution 1348 (XIII) of 1958, and Resolution 1472 (XIV) of 1959. For an overview of the establishment of UNCOPUOS see United Nations Office for Outer Space Affairs (27 September 2010) (www.oosa.unvienna.org/oosa/en/COPUOS/cop_overview. html), accessed on 29 January 2018.

13 Following the discussions, two new resolutions were passed by the UN General Assembly. The resolutions were primarily aimed at providing suggested practices for the coherent application of the Liability and Registration Conventions. See Fabio Tronchetti, Fundamentals of Space Law and Policy (2013), 17. 
4. By way of overview, Part II of this article will consider both the legal developments and major technological advances made in the "4th domain". Within this broader discussion, the key provisions regulating activities in space will be examined. Part III will then deconstruct each of the major provisions regarding the prohibition of militarization of outer space and the extent to which States are in compliance with those norms/obligations.

5. Of relevance to these discussions is the concept of "launch State", which has become difficult to identify from the perspective of liability of commercial activities in space, ${ }^{14}$ and the regulation of orbital space debris. In 2004, the UN General Assembly passed Resolution 59/115, ${ }^{15}$ which recommended that States adopt national space legislation to facilitate supervision of non-governmental entities under their jurisdictions; enter into agreements with other States in relation to joint launches and cooperation in line with the Liability Convention; and foster consistency of national space legislation with the provision of international law. ${ }^{16}$ The Resolution's recommendations are relevant to our current study as they provide the backdrop for the analysis of some of the prevailing issues surrounding the debates on the use of space by States.

6. Commentators such as Tronchetti note that the prevailing issues currently dominating the space law debate also include the regulation of orbital space debris; the financing of space assets; and management of space traffic. ${ }^{17}$ However, for the purposes of this article, the authors assert that the areas of key concern that necessitate further analysis are the incremental militarization/weaponization and exploitation of outer space.

7. Part IV of the article will then consider existing examples of incremental militarization, in addition to examining scenarios which could become a technological reality in the foreseeable future. Could (in analogous terms to "action" taken by one State against another State's nuclear enrichment facility prior to weaponization of its nuclear programme) State A “intercept" the activities of State B who wishes to command a dual use military/civilian facility in outer space? For example, State A may seek to take "anticipatory" (or more likely, "pre-emptive") action at launch against State B's space craft to prevent the successful delivery of crucial materials to either

14 Ibid. The advances made, and the presence of commercial operators have challenged the traditional understanding of a "launching state," which would normally be attributed to the State from whose territory or facility the launches take place.

15 The UN General Assembly Resolution 59/115 Application of the Concept of the "Launching State" was adopted on 10 December 2004.

16 Tronchetti, above n.13.

17 Ibid. 
State B's space-station or Doomsday weapon(s). Consequently, if State B successfully puts into orbit either a satellite or component part of a space station for military purposes, it will be in violation of its international obligations (Article IV of the OST) regarding its use of outer space. Clearly, such "anticipatory" or "pre-emptive" action by State A is difficult to reconcile or justify as a lawful invocation of self-defence as noted by the authors in Part IV. More problematic in such a discussion is the concept of "weaponization", and what actions are permissible/viewed as being permissible to prevent action taken to "weaponize" outer space. As noted above, is such action taken analogous to that of a pre-emptive attack on a nuclear facility ${ }^{18}$ - a highly envisageable scenario in the foreseeable future? The authors conclude that while the overall analogy of a pre-emptive strike against a military facility in space is undoubtedly similar to that of a strike against a terrestrial nuclear facility, the nature of space may require a recalibration when it comes to interception.

8. It is equally important to make clear that the authors wish to consider such action in the worst-case scenario e.g., State A's development of a Doomsday weapon to be launched from space: something presently within the realm of fiction, but which might be in the realm of fact in the not too distant future. The obvious caveat here is that we are not referring to conventional weapons stationed on satellites and targeting objects on earth, since this has been considered as an outdated concept. ${ }^{19}$ Rather, we use the expression of Doomsday weaponry to encompass non-conventional weaponry which may be technologically feasible in the not too distant future.

9. Overall, the authors contend that the closer that component (being delivered) is to the space-based facility, the more convincing the interception aspect "tracks" in terms of preventing weaponization. However, and somewhat perversely of course, State A, who perhaps wishes to prevent further weaponization by State B on the grounds of self-defence (against a future threat posed by State B), could itself veritably end up breaching the non-militarization principle. In tangent to these discussions is the issue of debris, and the way in which this interacts within the questions posed above. Technically of course, debris considerations remain firmly outside use of force calculations - a State is not required (at least from a use of force perspective) to compute "debris" when considering the lawfulness of a potential action. Nevertheless, the consequence of such a strike will invariably lead to debris in outer space-a feature which then adds another tier of analysis into the discussion, relatively untouched thus far within the literature with regards to this particular aspect.

18 Arman Sarvarian, The Lawfulness of a Use of Force Upon Nuclear Facilities in SelfDefence, 1 Journal of Use of Force and International Law (2014), 247-272.

19 For example, such objectives could be well achieved by airborne weapons and missiles. 


\section{Evolution of regulating activities in outer space}

10. The purpose of Part II within the overarching remit of this article is to examine the key provisions relating to use of outer space more generally, with specific attention to militarization/demilitarization. Part II, therefore, will provide the basis for a more forensic deconstruction of threshold, breach, and toleration in Parts III/IV.

11. Ever since the first mission into outer space, the international community has strongly endorsed the use of outer space solely for "peaceful" purposes. Despite the term "peaceful" repeatedly appearing in numerous UN instruments, and also in space law treaties, the term lacks a clear authoritative definition. The initial interpretation of "peaceful purposes" - that was palatable to both the United States and the Soviet Union, was "non-military", which was later translated by the US to mean "nonaggressive". ${ }^{20}$ The US deemed that all military uses of outer space were lawful so long as they remained "non-aggressive". ${ }^{21}$ In direct contrast, the Soviet Union consistently maintained the position that "peaceful" meant "non-military", thus rendering all military activities in outer space non-peaceful and unlawful. ${ }^{22}$ This requires us to pose two primary questions for our purposes - what is the current legal framework regarding the use of space, and perhaps more crucially, what are the legal parameters applicable to an attack on a military facility in space?

12. Early commentary from Oscar Schachter viewed outer space as being the "common heritage of mankind (CHOM)" even before the creation of the Outer Space Treaty, ${ }^{23}$ and extolled the need to develop common principles for outer space that would overcome purely national interests for the sake of security. A brief survey of the literature at this juncture reveals some disparity amongst commentators.

20 Ivan A. Vlasic, The Legal Aspects of Peaceful and Non-Peaceful Uses of Outer Space, in: Bhupendra Jasani (ed.), Peaceful and Non-Peaceful Uses of Space: Problems of Definition for the Prevention of an Arms Race (1991), 44-45. See also generally, "Peaceful" and Military Uses of Space: Law and Policy, Background Paper, Institute of Air and Space Law, McGill University, Canada (2005).

21 Vlasic, ibid. The author argues, "If 'peaceful' means 'non-aggressive', then it follows logically — and absurdly_ that all nuclear and chemical weapons are also 'peaceful', as long as they are not used for aggressive purposes." Perhaps, Vlasic is approaching his argument from the traditional international law/positivist Lotus Case maxim that, that which is not prohibited, is permissible.

22 Ivan A. Vlasic, Space Law and the Military Applications of Space Technology, in: Nandasiri Jasentuliyana (ed.), Perspectives on International Law (1995), 385.

23 Writing in 1952, Oscar Schachter declared that outer space was a common property of all mankind over which no nation could be permitted to exercise domination. See Oscar Schachter, Who Owns the Universe?, Colliers (22 March 1952), 36. A similar view was expressed by Alfredo Cocca, the Argentine space lawyer. See Alfredo A. Cocca, Principles for Declaration with Reference to the Legal Nature of the Moon, Proceedings from the 1st Colloquium on the Law of Outer Space (1959), 36. 
According to Joyner, under the CHOM doctrine, "common" space areas would be legally regarded as regions owned by no one, yet, managed by everyone; where sovereignty would be absent. ${ }^{24}$ For Joyner, CHOM is merely a philosophical notion with the potential to emerge and crystallize as a legal norm. Wolter meanwhile posits the strong view that through the inclusion of the mankind clause, the Outer Space Treaty (OST) propagates the five core elements of the CHOM principle to both the celestial bodies and outer space as a whole. ${ }^{25}$ In an earlier piece written in the 1980 's, ${ }^{26}$ Wolter argues that the idea of CHOM was embodied in UN General Assembly Resolution 1472, which recognized "the common interest of mankind as a whole in furthering the peaceful use of outer space", 27 and also in subsequent UN General Assembly Resolutions. Wolter is also quick to point out that the OST did not introduce the CHOM principle, as such, but expressed the central idea of said principle. $^{28}$

13. Jakhu applies a broad brushstroke to posit the argument that the current international space regime is one that is founded on legal principles, and that the object of the OST is clearly to "[...] enhance and protect the common interest of all mankind in the exploration and use of outer space for peaceful purpose." ${ }^{29}$ Blount, however, points out that it may be difficult to define the content of the norm of "peaceful purpose", and argues that it would mean non-aggressive, and therefore could be equal to the prohibition against the threat and use of force found in Article 2(4) of the UN Charter. ${ }^{30}$ Some even argue that international morality forbids the appropriation of

24 Christopher C. Joyner, Legal Implications of the Concept of the Common Heritage of Mankind, 35 ICLQ (1986), 190-199. The author argues that CHOM indicates an emergent principle of international law, and not yet a principle of international law erga omnes, and that it is neither the product of "instant custom" nor jus cogens.

25 See Detlev Wolter, Common Security in Outer Space and International Law (2006), 85-87.

26 Detlev Wolter, The Peaceful Purpose Standard of the Common Heritage of Mankind Principle in Outer Space Law, 9 ASILS International Law Journal (1985), 117-146. For a general discussion, see also Harminderpal Singh Rana, The Common Heritage of Mankind \& the Final Frontier: A Revaluation of Values Constituting the International Legal Regime for Outer Space Activities, 26 Rutgers Law Journal (1994), 225-250.

27 UN General Assembly Resolution 1472, 14 UN GAOR Supp. (No 16) at 5, UN Doc. A/4354 (12 December 1959).

28 Wolter, above n.26.

29 Ram S. Jakhu, Legal Issues Relating to the Global Public Interest in Outer Space, 32 Journal of Space Law (2006), 31-110.

30 P.J. Blount, Limits on Space Weapons: Incorporating the Law of War into the Corpus Juris Spatialis, Proceedings of the 51st Colloquium on the Law of Outer Space (2009). 
outer space for private ends either by nation-States, or by private individuals and corporate bodies. ${ }^{31}$ This leads the current authors to note the remaining uncertainty as to the status and application of the above principle.

14. There is also yet another perception prevalent in some quarters that, unlike with the Antarctic and the Deep Seabed, there are no general principles of CHOM present in international law. ${ }^{32}$ Space is infinite and does not have the same boundaries on Earth as land and sea. ${ }^{33}$ Moreover, there is no consensus on the demarcation of space. ${ }^{34}$ Fountain argues that humanity is "saddled with a legal framework conceived and created at the height of the Cold War", that CHOM is antithetical to the economic development of space resources, and argues for a much more liberal approach as the benefits to be derived from an active space industry are boundless. ${ }^{35}$ This invariably raises the question as to whether CHOM is contained as a clear provision in any of the international Conventions relating to the use of space, or in any of the UN General Assembly Resolutions. Does it operate as a safety-valve in case of militarization of space, or is it a hindrance for growth?

15. Some of the research carried out has also been used for defence purposes, (a number of platforms developed for use in space have duel use technology): for both

31 Gbenga Oduntan, Imagine There Are No Possessions: Legal and Moral Basis of the Common Heritage Principle in Space Law, 2 Manchester Journal of International Economic Law (2005), 30-58.

32 Hobe, above n.7. The author posits the view that one can probably agree to the fundamental position of the common heritage of mankind principle as regards outer space in the following way, i.e., "[...] that there should be no appropriation of any territory on celestial bodies, that there should be non-military usage of the celestial bodies, that this use should be undertaken in an ecologically responsible manner." Also, Article 1 of the Outer Space Treaty 1967 states that "The Exploration of outer space, including the Moon and other celestial bodies, shall be carried out for the benefit and in the interests of all countries, irrespective of their degree of economic or scientific development, and shall be the province of all mankind."

33 It can also be said that space is a non-physical and intangible medium where the Earth, like other planets, is in orbit, and distances are only measured by the distance between one planet/asteroid/satellite to the other. Again, the "measurements" are Earth-based.

34 Jackson Maogoto, The Militarisation and Weaponisation of Outer Space-From Playground to Battleground: Legal Perspectives on the Use of Force (2007), 24. The author notes that despite the development of a substantial body of Space Law and evolution of many customary principles, there is no broad-based consensus on the demarcation of air space and outer space.

35 Lynn M. Fountain, Creating Momentum in Space: Ending the Paralysis Produced by the "Common Heritage of Mankind" Doctrine, 35 Connecticut Law Review (2003), 1753-1787. The author advocates a free-market approach operating under an international regulatory umbrella, as the rewards could be immeasurable. 
civilian and military purposes. ${ }^{36}$ Of particular interest are the military use of outer space, developments in launch technology (involving multiple actors), regulation of space debris, duel use space technology, and commercial activities in space including space tourism. The beginning of the space race/age as a new era was thought to have the potential for the betterment of humankind, but some viewed the era as an opening for future military uses and conflict. ${ }^{37}$ As of 2014 , the number of military satellites in space numbered close to $300,{ }^{38}$ and as of 30 June 2016, the amount of operating satellites in orbit totalled $1419 .{ }^{39}$ The satellites together with their capabilities are identified as "space assets" belonging to the respective States that launched them into space. ${ }^{40}$ Satellites could be either single use or dual use, but they are increasingly the latter due to the expensive nature of launching them into space. ${ }^{41}$

16. It is now accepted that most armed forces are heavily dependent on satellites for communication, surveillance, early warning, signal intelligence, and meteorological information, to name a few uses. ${ }^{42}$ The statistics concerning satellites, as detailed above, suggest that outer space to a great extent remains unregulated. The key players

36 See for example Dave Webb, Space Weapons: Dream, Nightmare or Reality?, in Natalie Bormann and Michael Sheehan (eds.), Securing Outer Space (2009), 26. The author notes the US practice, where to save duplication costs, both military and civilian standards have been forced together and been combined into "dual use" programmes. This also means that the aerospace industry depends on military contracts. The author also notes that Russia has several dual-use Glonass, which is the equivalent of the US Global Positioning Systems (GPS).

37 Jakhu, above n.29. The author argues that the OST is not a mere a collection of idealistic goals without legal implications, and that the intention was to create binding obligations on the States. In the author's view the provisions are to be interpreted and understood according to the international rules of treaty interpretation and any interpretation based from purely nationalistic perspectives is not legally valid.

38 See CSEWI, "Number of Military Communication Satellites by Country," (18 February 2014) (http://csewi.org/number-of-military-communication-satellites-bycountry/), accessed on 29 January 2018. It is noted that the US has the most number of military satellites (129), some of which are used solely for military purposes (non-dual use), followed by Russia (75), China (35), Israel (9), France (8), UK and Germany (7 each), Italy (6), and India (4).

39 Union of Concerned Scientists, UCS Satellite Database (11 August 2016) (www. ucsusa.org/nuclear-weapons/space-weapons/satellite-database\#.WCR4pdxyF1Q), accessed on 29 January 2018. Here again, the US is leading the way with 576 satellites, followed by Russia with 140, China with 181, and the rest making up 522 satellites.

40 N.B.: Article VIII of OST provides that liability is tied to the concept of launching State.

41 Satellites are positioned in certain orbits—Low Earth Orbit (LEO), Medium Earth Orbit (MEO), Elliptical Orbit, Geo Stationary Earth Orbit, etc.

42 See for e.g., US Military GPS Usages: Army Technology (www.army-technology. com/projects/gps-block-iif-satellites/), accessed on 29 January 2018. 
(and other smaller players too) have successfully explored and utilized space for military purposes-if not for stationing nuclear arsenals, at least for providing logistic support for Earth-based defence activities. It can be said that activities in space are regulated, subject to interpretation of the key treaty provisions. In sum, efforts to interpret treaty provisions relating to space have witnessed a "stalemate".

\section{The demilitarization of outer space?}

17. Having surveyed and detailed the historical context, Part III will consider the specific framework, which regulates (or not) activities in outer space from a military perspective. It is also important to note that the applicable jus ad bellum framework central to the key tenets of this argument will be briefly surveyed in Part IV. In Maogoto's view the jus ad bellum framework regulates (or, indeed, should regulate) any potential militarization of outer space. ${ }^{43}$ Tracing the major treaties that regulate States' activities in outer space, Maogoto notes that at the outer space conference in 1960, which laid the ground work for the Outer Space Treaty (OST), ${ }^{44}$ the delegates were opposed to the peaceful use of military assets on celestial bodies. Article IV of the OST bars any State parties to the treaty from placing weapons of mass destruction in the Earth's orbit. ${ }^{45}$ Blount even posits that the OST shares one of the main underlying principles of the UN Charter. Article III of the OST specifically incorporates the UN Charter, which in turn bans the threat and use of force, but allows for selfdefence and Security Council sanctioned use of force. ${ }^{46}$

43 Jackson Maogoto, Technology and the Law on the Use of Force (2015).

44 Treaty on Principles Governing the Activities of States in the Exploration and Use of Outer Space, including the Moon and Other Celestial Bodies 1967. Viewed as the basis of international space law, the Treaty came into force on 10 October 1967. As of September 2015, 104 countries are parties to the treaty with a further 24 yet to complete the ratification process. Limited Test Ban Treaty 1963, Liability Convention on Damage Caused by Space Objects 1972, and The Anti-Ballistic Missile Treaty 1972.

45 Article IV: States Parties to the Treaty undertake not to place in orbit around the earth any objects carrying nuclear weapons or any other kinds of weapons of mass destruction, install such weapons on celestial bodies, or station such weapons in outer space in any other manner.

46 P.J. Blount, Targeting in Outer Space: Legal Aspects of Operational Military Actions in Space, Harvard National Security Journal (2012), 1-22. Blount also notes that the said doctrine of "peaceful purpose" is also contained in the legal principles applicable to outer space. See Declaration of Legal Principles Governing the Activities of States in the Exploration and Use of Outer Space, G.A. Res. 1962 (XVIII), U.N. Doc. A/RES/1962(XVIII) (13 December 1963). 
18. Maogoto in his analysis of the key treaties relating to the outer space, reasons that they serve to restrict the use of outer space as a theatre of war. ${ }^{47}$ Maogoto further contends that despite the measures put in place through the outer space conventions to prevent militarization in outer space, the key players with capabilities to operate in space are incrementally challenging the boundaries set by the regime. China, for instance, in 2007, used an anti-satellite weapon to down its own defunct weather satellite. ${ }^{48}$ The US in particular was highly critical of this action, ${ }^{49}$ which, it articulated alongside a more general concern regarding space debris. A year later in 2008, the US would seemingly contradict it's earlier "position" vis-à-vis China, when it chose to shoot down its inoperable spy satellite. The US justification was based on the grounds, that it had noxious substances on board, and that it wanted to avoid the same entering the Earth's atmosphere. ${ }^{50}$ Both China and the US could argue that what they sought to target was their own defunct/inoperable satellites, and that their actions were not aggressively aimed at another State's space assets. Regardless of this "supposed stance", the actions did capture and demonstrate the two States' military capabilities in space. Can these actions be viewed as militarization of space?

19. A somewhat similar question to that of the anti-satellite weapons (ASAT) emerges when one theoretically considers, if an intercontinental ballistic missilelexoatmospheric missile was technically in outer space before its re-entry, would that breach provisions of the existing legal regime? If one were to consider the above hypothetical question in the light of the travaux préparatoires of the Outer Space Treaty from the 1960s, the answer would be a likely "no". 51 Intercontinental ballistic missiles (ICBMs) traversing through outer space temporarily, are not regarded as being

47 Maogoto, above n.34. Maogoto takes up for analysis the Outer Space Treaty 1967, Limited Test Ban Treaty 1963, Liability Convention on Damage Caused by Space Objects 1972, and The Anti-Ballistic Missile Treaty 1972 and eventually concludes that the weakness of existing treaties is seen in other activities relating to the exploitation of the systems, and neutering the principle of "peaceful use".

48 The People's Republic of China (PRC) brought down its defunct weather satellite, the FY-1C Polar Orbit at an altitude of 865 kilometres with a mass of $750 \mathrm{~kg}$, through the use of a "kinetic kill vehicle".

49 In this context, China could probably invoke Article VIII of the Outer Space Treaty, which would give it autonomy to dispose of its own "property" in this way.

50 Although the US complained about China's actions, it was soon to follow suit. See Mark Kaufman and Josh White, Spy Satellite's Downing Shows a New US Weapon Capability, The Washington Post (22 February 2008), (www.washingtonpost.com/ wp-dyn/content/article/2008/02/21/AR2008022100641.html), accessed on 29 January 2018.

51 See, for example, Jonathan Halpern, Antisatellite Weaponry: The High Road to Destruction, 3 Boston University ILJ (1985), 167, 181; and the travaux preparatoires themselves: "Treaty on Principles Governing the Activities of States in the Exploration and Use of Outer Space, Including the Moon and Other Celestial 
regulated by space law. Maogoto's argument that the key tenets of space law do not preclude the broader "militarization" of outer space per se (in the sense of "military usage", such as the deployment of intelligence satellites for military purposes) is difficult to dispute. ${ }^{52}$ One can posit the view that militarization of this kind is a very different militarization, wherein there is a direct use of force in/from space. Furthermore, one could also argue that such a discussion concerns "passive" military activities ${ }^{53}$ in outer space rather than something more "offensive".

20. Notably, there is a lack of oversight in terms of launch of military satellites in the past two decades by State parties who are not viewed as key players - States other than the US, Russia, China or European States. The lack of oversight also extends to the enforcement of the laws as identified in the OST and other treaties relating to the use of outer space. The unregulated activities not only include launching of satellites — both military and domestic — but also the resulting debris from the activities carried out in space.

21. As mentioned earlier, space debris could cause collisions and may lead to confrontation, etc., in space. Any activity carried out in space, like on Earth, will leave debris in space. According to NASA, Earth's orbit is heavily packed with an estimated 500,000 pieces of debris, with the oldest one being the 1958 Vanguard 1 research satellite. ${ }^{54}$ Space debris could range from a dusty particle to a hatch cover from a used satellite and/or a metal fragment from a "launch". 55 Space debris can be defined as any human-made object in orbit that is not in active use. ${ }^{56}$ Debris could present a threat to the safety of the satellites in orbit, as demonstrated in 1996 when a French satellite was damaged by fragments from a rocket launch, and again in 2009 when a used Russian satellite collided with a US iridium satellite, resulting in more debris. ${ }^{57}$

Bodies" (16 September 1966), UN Doc A/AC.105/35 Annex III - WP.6/ Rev. 1 (note particularly the US's interpretation of Art IV of the Outer Space Treaty).

52 See CSEWI, above n.38. Currently, there are close to 300 military satellites in orbit.

53 This aspect of the law is discussed in more detail in Part IV.

54 See Neville McCarthy, Space Debris and Satellites, Statista.com (8 November 2013) (www.statista.com/chart/1609/space-debris-and-satellites/), accessed on 29 January 2018.

55 See Loretta Hall, The History of Space Debris, Space Traffic Management Conference, Paper 19 (6 November 2014). The author notes that since the launch of Sputnik I, the US Air Force has maintained a catalogue of objects in orbit, which constitutes items larger than $10 \mathrm{cms}$. (4 inches) identified by launch date, country of origin, and launch site. See also T.S. Kelso, Space Surveillance, Satellite Times (September/October 1997) (http://celestrak.com/columns/v04n01/), accessed on 29 January 2018.

56 Roger Thompson, A Space Debris Primer, 16 Crosslink (Fall 2015), 4.

57 Brian Weeden, 2009 Iridium-Cosmos Collision Fact Sheet, Secure World Foundation (10 November 2010) (https://swfound.org/media/6575/swf_iridium_ cosmos_collision_fact_sheet_updated_2012.pdf), accessed on 29 January 2018. See 
Although numerous techniques, including capture mechanisms and laser beams, are considered, debris may be a difficult problem to solve due to technological and economic constraints. ${ }^{58}$ Regard should also be had to the fact that space is not a domain exclusively reserved for the States, both small and great, but also for private enterprise, which brings with it an array of parties, their respective rights, obligations and the resulting problems to the fore. ${ }^{59}$

22. Provisions of the Partial Test Ban Treaty (PTBT) 1963 bans nuclear weapon tests in the atmosphere, in outer space, and under water, ${ }^{60}$ which has so far been adhered to by the signatories to the treaty. ${ }^{61}$ Nevertheless, the PTBT does not prohibit the placement of nuclear weapons in outer space. This lacuna is sought to be filled by Article IV, paragraph 1 of the OST, which imposes constraints on the military use of celestial bodies. ${ }^{62}$ Worryingly, Article IV, paragraph 2 does not prohibit the use of military personnel for scientific research or any other peaceful purposes-clearly allowing for the placement/participation of military personnel in such scientific activities, paving the way for any findings to be used for military purposes. Article IV is not free of ambiguities, as it has given rise to disputes with regard to the interpretation of

also Thompson, ibid., where the author notes that the said collision incident added more than 2200 fragments to the catalogue of tracked objects, and hundreds of thousands of smaller fragments.

58 Hall, above n. 55 .

59 The US passed legislation in 2015, facilitating private parties to exploit minerals found in asteroids. Luxemburg, a much smaller European State renowned for its liberal banking laws published its draft legislation in November 2016, in similar lines with the US Act of 2015.

60 The Treaty Banning Nuclear Weapon Tests in the Atmosphere, Outer Space and Under Water, was signed on 5 August 1963, 480 U.N.T.S. 43, and entered into force on 10 October 1963. Article I reads as, "Each of the Parties to this Treaty undertakes to prohibit, to prevent, and not carry out any nuclear weapon test explosion, or any other nuclear explosion, at any place under its jurisdiction or control: (a) in the atmosphere, beyond its limits, including outer space; or under water, including territorial waters or high seas; $[\ldots]$. .

61 The notable absentee from the list of signatory states to the PTBT is the People's Republic of China. China has unilaterally declared not to conduct such activities prohibited by the PTBT.

62 Article IV, Paragraph 2:

The Moon and other celestial bodies shall be used by all States Parties to the Treaty exclusively for peaceful purposes. The establishment of military bases, installations and fortifications, the testing of any type of weapons and the conduct of military manoeuvres on celestial bodies shall be forbidden. The use of military personnel for scientific research or for any other peaceful purposes shall not be prohibited. The use of any equipment or facility necessary for peaceful exploration of the Moon and other celestial bodies shall also not be prohibited. 
the expression "placement" ${ }^{63}$ and also with regard to the interpretation of "weapons"-if nuclear devices used to deflect Near Earth Objects (NEOs) that pose a threat to the Earth can be regarded as a weapon. ${ }^{64}$ Also, the OST does not ban conventional weapons in outer space. ${ }^{65}$ It should also be noted that the core of the existing Space treaties were formulated at a time when very few States were capable of "space-faring", and cannot be expected to cover a modern day State's actions towards establishing hegemony in outer space. ${ }^{66}$

23. In Su's opinion, existing international law only prohibits certain categories of space weapons, ${ }^{67}$ and Su notes that scholarly debates have addressed the question as to which points on the continuum the prohibition should be placed, i.e., research, development, testing, development and use-clearly highlighting a lacuna in international law. Su also opines that given the utmost confidentiality and sensitivity attached to space activities/programmes, intrusive verification measures—such as

63 See e.g., Kai-Uwe Schrogl and Julia Neumann, Article IV, in: Stephan Hobe, Bernhard Schmidt-Tedd, and Kai-Uwe Schrogl (eds.), Cologne Commentary on Space Law, Vol. 1 (2009), 70 at 79. The authors argue that a full rotation in orbit is not required in order to amount to "placement in orbit". See also Sandeepa Bhat and V. Kiran Mohan, Anti-Satellite Missile Testing: A Challenge to Article IV of the Outer Space Treaty, 2 National University of Juridical Sciences Law Review (2009), 205 at 209, who express the view that Article IV does not ban nuclear armed "pop-up" ASAT interceptors that ascend directly to their targets without entering into orbit.

64 See e.g., Joseph Packer, Jeffrey A. Kurr, and Adam Abelkop, The Policy Trajectory of United States Asteroid Deflection Planning, 1 Timely Interventions: An Transnational Journal of Public Policy Debate (2013), 2 at 5-6. "Nuclear weapons" are defined by the International Court of Justice as "explosive devices whose energy results from the fusion or fission of the atom". See Legality of the Threat or Use of Nuclear Weapons, Advisory Opinion, ICJ Reports 1996, 226, at 243. See also Jinyuan Su, Measures Proposed for Planetary Defence: Obstacles in Existent International Law and Implications for Space Arms Control, 34 Space Policy (2015), 1-5.

65 It has been posited by some writers that the "technical feasibility" of such placement was not foreseeable at the time the OST was negotiated. See Karl D. Herbert, Regulation of Space Weapons: Ensuring Stability and Continued Use of Outer Space, 12 Astropolitics: The International Journal of Space Politics \& Policy (2014), 1; Jinyuan Su, Space Arms Control: Lex Lata and currently Active Proposals, Asian JIL (2015), 1-33.

66 See Steven Freeland, Applying the Jus in Bello to Military Uses of Outer Space: A Square Peg in a Round Hole?, in: Patricia Margaret Sterns, Leslie I. Tennen (eds.), Private Law, Public Law, Metalaw and Public Policy in Space: A Liber Amicorum in Honor of Ernst Fasan, Vol. 8 (2016), 109-122. The author notes that many of the activities carried out in space could not have been within the contemplation of the drafters of the UN Space Treaties.

67 Su, above n.64. 
on-site inspections - may not be a workable option. ${ }^{68}$ Equally, space assets are increasingly becoming dual use, which means a satellite could be used for both civilian and military purposes, by the States that launch them into space at any given point in time. A satellite in space identified and thought to be in orbit performing civilian activities could double up to perform defence activities like logistic support for drone warfare (GPS), surveillance, etc. This flexibility in use of the satellites does pose the problem, and the inevitable question, whether space has already been weaponized/ militarized.

24. Recent proliferation in the number of space actors, and an increased activity of ASAT by some of the States, prompt us to take a closer look at Article IX of the OST. In Cheng's view, Article IX does not limit the use of outer space solely for peaceful or non-military purposes, and a reading of both Articles IX and XI only makes it abundantly clear that they "merely" promote international co-operation in the "peaceful exploration and use of outer space". ${ }^{69}$ Moreover, Cheng posits the argument that barring Article IV, nowhere in the OST is there a restriction on State parties to the exploration or use of outer space exclusively for peaceful purposes. Cheng also notes that there is no particular provision in the OST limiting the military use of outer space, but only a desire to promote peaceful exploration of outer space. Furthermore, in Cheng's opinion, even the more extreme form of teleological interpretation cannot ferret out any shared resolve in the OST to impose any restriction to use outer space solely for peaceful purposes, and/or not to use it for military purposes. ${ }^{70}$ Article IX, according to Rendleman and Mountain, enshrines the three guiding principles for activities conducted by space-faring States, viz., co-operation, mutual assistance, and due regard. ${ }^{71}$ However, they are quick to point out that there is a lack of a clear legal definition for "cooperation," and that the principles of "mutual assistance" are derived from the maritime tradition of "render assistance", which is found codified in the Law of the Sea. While, the term "due regard" is not defined

68 Ibid. See also Kenneth S Blazejewski, Space Weaponization and US-China Relations, 2 Strategic Studies Quarterly (2008), 33; Jinyuan Su, Towards an Effective and Adequately Verifiable PPWT, 26 Space Policy (2010), 152.

69 Bin Cheng, Properly Speaking, Only Celestial Bodies Have Been Reserved for Use Exclusively for Peaceful (Non-Military) Purposes, but Not Outer Void Space, in: Michael N. Schmitt (ed.), International Law Across the Spectrum of Conflict: Essays in Honour of Professor L.C. Green On the Occasion of His Eightieth Birthday, Vol 75 (2000), 81-117. The author also notes that treaties do not normally contain any binding obligations, and that there is nothing in the Preamble to the OST which suggests that outer space can only be used for peaceful purposes.

70 Ibid., 92.

71 James D. Rendleman and Sarah M. Mountain, Evolving Spacecraft Operator Duty of Care, in: Tommaso Sgobba and Isabelle Rongier (eds.), Space Safety is No Accident (2015), 389-404, 394. See also Su, above n.64. 
in the OST, a good-faith interpretation would mean that all State Parties consider the legal rights of others while conducting space activities. ${ }^{72}$

25. Su argues that the "three pillars" identified in Article IX does not limit a State's right to conduct ASAT tests per se, but only imposes certain obligations on their external effects and on procedural formalities. ${ }^{73}$ It is pertinent to mention here that any ASAT activity will leave space debris — substantial or otherwise, depending on the nature and the extent of test. Su notes that ASAT tests carried out in Low-Earth Orbits (LEOs) and Geostationary Orbits (GEOs) produce large amounts of space debris, which would be contrary to the "corresponding interests" of other State Parties. ${ }^{74}$ Can one then conclude that a space-faring State will be in violation of Article IX of the $O S T$, if they were to conduct an ASAT test, either in LEO or GEO?

26. On-going discussions concerning the Draft Treaty on the Prevention of Placement of Weapons in Outer Space and the Threat or Use of Force against Outer Space Objects (PPWT) ${ }^{75}$ in the Conference on Disarmament, ${ }^{76}$ and the European Union's proposed Code of Conduct for Outer Space Activities (ICoC) ${ }^{77}$ raise further questions. The draft PPWT does not offer much clarity on militarization or weaponization in outer space. The PPWT, although officially submitted by a China-Russia led initiative in 2008, has been revised to reflect the concerns and criticisms raised by the US and other States. The draft that is currently being discussed is the updated text from 2014. Most interestingly, the 2014 text contains clarifications on various definitions including, "outer space," "weapons in outer space", and "use of force". 78 The inclusion of the above definitions is a clear indication that the current laws in force lacks clarity about "weapons" and "use of force" in outer space. Furthermore, the draft also contains provisions for the recognition of the rights of individual and

\section{Ibid.}

73 Su, above n.64.

74 Ibid.

75 This draft was proposed by both China and Russia.

76 See United Nations, Conference on Disarmament, 2015 (http://nti.org/18TAR), accessed 21 April 2016. The Conference on Disarmament which is the main multilateral disarmament negotiating forum of the international community has a membership of sixty-five Member States.

77 European Union External Action, International Code of Conduct for Outer Space Activities (Draft), European External Action Service (31 March 2014) (http://eeas.europa.eu/non-proliferation-and-disarmament/outer-space-activities/ index_en.htm), accessed on 29 January 2018.

78 Analysis of the 2014 Russian-Chinese Draft "Treaty on the Prevention of the Placement of Weapons in Outer Space, the Threat or Use of Force Against Outer Space Objects" (PPWT) (CD/1985), CD/1998. 
collective self-defence, and the elaboration of a dispute resolution mechanism, ${ }^{79}$ which is of relevance to our current discussion. Although the PPWT draft contains a definition of "weapons in outer space", ${ }^{80}$ it does not address terrestrial-based ASATs directly, but only indirectly in Article II by including the obligation, "not to resort to the threat or use of force against outer space objects of State Parties to the Treaty." 81 The militarization of outer space, particularly with regards to ASAT, has therefore already happened. $^{82}$

\section{Breach and thresholds of militarization}

27. By way of overview, Part IV envisages five key scenarios, within which we wish to deconstruct the overarching theme of incremental militarization/demilitarization. This section will examine these scenarios in turn, and the typology will be set out as follows: first, to consider the extent to which such actions within the scenarios lawfully satisfy jus ad bellum requirements_-recalling of course, the seminal provision contained in Article 2(4) of the United Nations Charter prohibiting the threat or use of force by States. ${ }^{83}$ Given that the scope of this section is not to deconstruct Article 2(4) or further scrutinize perennial debates surrounding the accepted exceptions (of self-defence and collective security), jus ad bellum discussions will be confined to its broad contours. Instead, focus will predominantly cover breach and thresholds of militarization.

79 The 2008 draft was the first treaty proposal to contain a definition of "outer space," to mean "the space above the Earth in excess of $100 \mathrm{~km}$ above the sea level." The 2014 draft abandoned the above definition leaving it for future discussions. See generally Su, above n.64.

80 Weapons in outer space has been defined as, "any outer space object or component thereof which has been produced or converted to destroy, damage or disrupt the normal functioning of objects in outer space, on the Earth's surface or in its atmosphere, or to eliminate human beings or components of the biosphere which are important to human existence, or to inflict damage on them by using any principles of physics."

81 Article II of the 2014 PPWT reiterates the obligation of non-threat or use of force as enshrined in Article 2 (4) of the UN Charter. See generally Su, above n.64.

82 One could also note the provisions of the Draft International Code of Conduct for Outer Space Activities 2014 (ICoC). Although ICoC does not intend to address arms control, it would have an indirect impact on military activities in space.

83 See Grimal and Sundaram, above n.1, who provide an overview, where they note in particular the following works: Olivier Corten, The Law Against War: The Prohibition on the Use of Force in Contemporary International Law (2010), 50 197; Thomas M. Franck, Recourse to Force: State Action Against Threats and Armed Attacks (2002), 11-19; Nico Schrijver, The Ban on the Use of Force in the UN Charter, in: Marc Weller (ed.), The Oxford Handbook of the Use of Force in International Law (2015), 466. 
28. Secondly, therefore, the main tier of analysis will consider how the action within each scenario complies (or not) with the various provisions which purport to regulate/prevent the militarization of outer space. ${ }^{84}$ And finally, the assertion that while such scenarios may indeed be hypothetical, they demonstrate the level to which space is indeed already capable of being "militarized" incrementally without States having recourse to a full-blown modern incarnation of Strategic Defense Initiative (SDI)/"Star Wars Programmes". 85

29. In terms of overarching explanation in the more linear sense, the authors contend that the closer the interception is in terms of proximity to launch (more desirable, of course, from a strategic sense), the less likely it is that the relevant legal parameters will be satisfied. One must also be cautious, and note that there are distinct points of departure from "standard" missile interception-here the object/ weapon at launch prior to entry into outer space is not necessarily a weapon as such:

Scenario 1: Interception by State B against a satellite launch (at launch stage) by State A, delivering nuclear warheads to State A's space station.

Scenario 2: Interception by State B against State A's satellite which, is exiting Earth's atmosphere and entering outer space.

Scenario 3: Interception against the "delivery vehicle/cargo ship" that has successfully delivered its military payload to the space station and is re-entering Earth's atmosphere.

Scenario 4: A cyber-attack against a land-based command and control centre (which has kinetic consequences in space). NB: Even if there are non-kinetic consequences, there is support within the literature that a violation of Article 2(4) may have taken place. ${ }^{86}$

Scenario 5: Could a satellite providing GPS for both military and civilian purposes (dual use) be in violation of key tenets of the outer space framework?

84 Clearly, debris cannot and should not form part of the requirements needed to satisfy Article 51 of the UN Charter. It is an "add on" which, clearly, must be considered thereafter. If action taken is Article 51 compliant, then while debris may be present, it does invite the following question as to who should be liable-the "intercepting" State, the "carrying" State or both.

85 The SDI envisaged the recourse to space-based lasers as a means of interception. See Paul Rogers, Towards an Ideal Weapon? Military and Political Implications of the Airborne and Space-Based Lasers, 17 Defence Analysis (2001), 73-87.

86 See Grimal and Sundaram, above n.1, who note the following supporting commentary: Ian Brownlie, International Law and the Use of Force by States (1963), 362. For a contrasting view see Daniel B. Silver, Computer Network Attack as a Use of Force Under Article 2(4), 76 International Law Studies (2002), 73, 80-2; Tom J. Farer, Political and Economic Coercion in Contemporary International Law, 79 AJIL (1985), 405. 


\section{IV.A. Analysis of scenarios}

30. By way of explanation, the following scenarios will consider the lawfulness of action from a jus ad bellum perspective, but more importantly for the purposes of this article, the extent to which the OST regime is applicable and/or being breached by both the "intercepting" State and the "carrying" State in terms of militarization. The "intercepting" State could argue that its actions are strategically justified in order to prevent the "carrying" State from weaponizing an existing space facility-such preventative action is problematic once the "carrying" by State B has transferred resources to outer space, and then is compounded once weaponization has occurred. However, preventive action of this nature may be evidently in breach of both the jus

ad bellum (particularly since interception would be difficult to reconcile within the realm of self-defence) and $\mathrm{CHOM}$ framework.

\section{Scenario 1: Interception by State B against a satellite launch (at launch stage) by State A, delivering nuclear warheads to State A's space station}

31. Potentially, this is the most problematic of scenarios, for obvious and understandable reasons, in terms of reconciling such an action within the confines of self-defence and its stringent requirements of necessity and proportionality. ${ }^{87}$ Additionally, States would face initial difficulty in satisfying the primary hurdle/requirement for lawfully

87 See Grimal and Sundaram, above n.1, who note that necessity encapsulates the concept of last resort and, if non-forcible measures were a reasonable alternative in the circumstances, that they were explored/exhausted. For a useful overview of the applicable literature regarding this point on necessity, see James A. Green, The Ratione Temporis Elements of Self-Defence, 2 Journal on the Use of Force in International Law (2015), 100-1; Georg Schwarzenberger, The Fundamental Principles of International Law, 87 Recueil des cours (1955), 97; Yoram Dinstein, War, Aggression and Self-Defence (2011), 187, 232; Myra Williamson, Terrorism, War and International Law: The Legality of the Use of Force against Afghanistan in 2001 (2009), 115; Judith Gardam, Necessity, Proportionality, and the Use of Force by States (2004), 6 and 11. Proportionality meanwhile dictates that the force employed must not be excessive with regard to the goal of abating or repelling the attack. See Avra Constantinou, The Right of Self-Defence under Customary International Law and Article 51 of the UN Charter (2000), 57. 159-61. See also Gamal Moursi Badr, The Exculpatory Effect of Self-Defense in State Responsibility, 10 Georgia Journal of International and Comparative Law (1980), 1; David Kretzmer, Killing of Suspected Terrorists: Extra Judicial Executions or Legitimate Means of Defence?, 16 EJIL (2005), 171-212; David Kretzmer, The Inherent Right to Self-Defence and Proportionality in Jus ad Bellum, 24 EJIL (2013), 235, 237; Sina Etezazian, The Nature of the Self-Defence Proportionality Requirement, 3 Journal on the Use of Force and International Law (2016), 260, 264-7; Theodora Christodoulidou and Kalliopi Chainoglou, The Principle of Proportionality from a Jus ad Bellum Perspective, in: Marc Weller (ed.), The Oxford Handbook of The Use of Force in International Law (Өxferd-2015), 1189-99. 
invoking their inherent right to self-defence (at least from a "restrictive" Charter perspective), namely, having suffered an armed attack whose severity satisfies a qualitatively grave use of force threshold. ${ }^{88}$ In this scenario (Scenario 1 ), military force is potentially being taken against a non-imminent and latent threat of an armed attack rendering it fully within the category of a pre-emptive strike. ${ }^{89}$ Such action cannot

88 Don W. Greig, Self Defence and the Security Council: What Does Article 51 Require?, 40 ICLQ (1991),366-402. It should be noted that Article 51 of the UN Charter remains silent as to imminence. See Grimal and Sundaram, above n.1, who note that the ICJ's judgments in the Nicaragua case and the Oil Platforms case and from commentators, indicate that an armed attack should be defined as: "the most grave form of the use of force," i.e., a qualitatively grave use of force beyond a use of force simpliciter. Military and Paramilitary Activities in and Against Nicaragua (Nicaragua v United States of America), Merits, ICJ Reports 1986, 14, para.191. Case Concerning Oil Platforms (Islamic Republic of Iran v United States of America), Merits, ICJ Reports 2003, 161, para.51. See also James A. Green and Francis Grimal, The Threat of Force as an Action in Self-Defence Under International Law, 44 Vanderbilt Journal of Transnational Law (2011), 285; Constantinou, above n.87.

89 N.B.: The authors define pre-emptive self-defence as action taken against a latent and temporally remote threat. See James A. Green and Francis Grimal, The Threat of Force as an Action in Self-Defense Under International Law, 44 Vanderbilt Journal of Transnational Law (2011), 285-329, at 299. See also Constantine Antonopoulos, Force by Armed Groups as Armed Attack and the Broadening of Self-Defence, 55 Netherlands International Law Review (2008), 159, 172; Niaz A. Shah, Self-Defence, Anticipatory Self-Defence and Pre-Emption: International Law's Response to Terrorism, 12 JCSL (2007), 95, 111. See, e.g., the categorical rejection of the notion of pre-emptive attack by the Non-Aligned Movement in the declaration that emerged from the Fourteenth Summit of Heads of State or Government of the Non-Aligned Movement: Non-Aligned Movement, Final Report Covering the 14th Conference of Heads of States or Governments of the Non-Aligned Movement (11-16 September 2006), (http://cns.miis.edu/nam/docu ments/Official_Document/14NAMSummit-Havana-Compiled.pdf), para.22.5, accessed 29 January 2018. See e.g., Tarcisio Gazzini, The Changing Rules on the Use of Force in International Law (2005), 174, 238 (arguing that a State's practice "[...] is neither quantitatively nor qualitatively consistent enough to affirm the existence of a right to anticipatory self-defence, a development that would stretch beyond recognition the notion of self-defence itself'). See also Christopher Greenwood, International Law and the Pre-Emptive Use of Force: Afghanistan, AlQaida, and Iraq, 4 San Diego ILJ (2003), 7, 12-16 (noting that the right to the exercise of "anticipatory self-defence is confined to instances where the armed attack is imminent"); Miriam Sapiro, Iraq: The Shifting Sands of Pre-Emptive Self-Defence, 97 AJIL (2003), 599-603 (taking the view that although it is possible to interpret the law to permit defensive action in the face of imminent threat, it will be not only difficult but also dangerous to stretch it further). 
conceivably fall within a strict Charter interpretation of Article 51. ${ }^{90}$ The armed attack requirement has not been fulfilled and could never be manipulated as such in this instance. ${ }^{91}$ Moving towards the more elastic interpretations of self-defence from the position of anticipatory self-defence is equally problematic. ${ }^{92}$ The language of the Caroline Incident is difficult to satisfy. ${ }^{93}$ From a strategic perspective, one could query

90 Article 51 is explicit in its requirement that the State exercising the right must have suffered an "armed attack". Don W. Greig, Self Defence and the Security Council: What Does Article 51 Require?, 40 ICLQ (1991), 366-402. It should be noted that Article 51 of the UN Charter remains silent as to imminence. However, some commentators support a more liberal interpretation of Article 51, which would allow a State to invoke self-defence lawfully when faced with a sufficiently serious and imminent threat of suffering an armed attack. On this point, see Terry D. Gill, The Law of Armed Attack in the Context of the Nicaragua Case, 1 Hague YIL (1988), 30, 35.

91 See ibid.

92 Anticipatory self-defence, assuming one subscribes to the doctrine (which, many don't). See Jackson Maogoto, Battling Terrorism: Legal Perspectives on the Use of Force and the War on Terror (2005), 111-49 (providing a useful overview of the main arguments concerning this issue and a survey of the vast literature); Christine Gray, The US National Security Strategy and the New "Bush Doctrine" on PreEmptive Self-Defence, 1 Chinese JIL (2002), 437, 438 (describing the "radical new doctrine of international law on the use of force"); Greenwood, above n.88; Christian M. Henderson, The 2006 National Security Strategy of the United States: The Pre-Emptive Use of Force and the Persistent Advocate, 15 Tulsa Journal of Competition and International Law (2007), 1, 2 (characterizing the 2006 reassertion of the doctrine of pre-emptive military action as "surprising"); Abraham D. Sofaer, On the Necessity of Pre-Emption, 14 EJIL (2003), 209, 210 (noting that traditional deterrence is ineffective against terrorists). See, generally, Sapiro, above n.89 (arguing that the United States should refine its position on the pre-emptive use of force). On this point, see Grimal and Sundaram, above n.1, referring to Green and Gill. Green and Gill both view the judgment in Nicaragua as leaving the door ajar for anticipatory self-defence providing such action is taken against a "threatened armed attack". Furthermore, the threat posed will need to be qualitatively grave (a threatened armed attack), and also imminent in order for self-defence to be lawfully invoked. On this point, see Shah, above n.89, 101-4, 111-9 (describing the gravity and immediacy of the threat required to justify self-defence under international law).

93 "In terms of a state being able to [s] how a necessity of self-defence, instant, overwhelming, leaving no choice of means, and no moment for deliberation. It will be for it to show, also, that [... it] did nothing unreasonable or excessive; since the act, justified by the necessity of self-defence, must be limited by that necessity, and kept clearly within it." Letter dated 27 July 1842, from Daniel Webster to Lord Ashburton (1841-42) XXX British and Foreign State Papers 193-4, extract taken from Webster's earlier letter to Henry S. Fox dated 24 April 1841 (1840-1), XXIX British and Foreign State Papers 1137, 1137-8 (Caroline formula). It is important to underscore that when States have debated the lawfulness of anticipatory action 
that interception in outer space is too "problematic"-albeit a concern which is more strategic rather than legal. Thus, the logical "legal conclusion" would undoubtedly return a verdict of "unlawful", since the action envisaged would be pre-emptive in nature.

32. Even if it were simply a case of the delivery craft/satellite transporting the equipment, such equipment would need to be installed, or potentially "enriched" (in the non-uranium sense). However, one could equally question whether parameters change if interception takes place either from land-based or space-based strike platforms. Tempting though it is to delineate between the two, the law on self-defence would presumably offer no such distinction. Perhaps the only variable as such which might impact here would be if the military facility in space happens to be stationed next to another State's space station, and the delivery of the satellite was the crucial last stage before the military facility could be operational, then, in turn, attack the space station. Possibly only then might there be more a sense of immediate urgency, given that it is being directly "threatened". On this point, one could analogize with the strategic desirability of halting a particular programme prior to weaponization, similar to a "Stuxntet scenario". ${ }^{94}$

post-1945, the focus and discussion were not exclusively limited to the question of imminence. By way of overview, State practice evidences not only that the attack must be imminent, but also reflects the ICJ's pronouncement that there is a further consideration - that the imminent attack must attain a certain threshold in terms of gravity (i.e., there needs to be an imminent "armed attack"). Historical examples worth noting include discussions within the UN Security Council that ensued following the 1981 Israeli attack upon the Iraqi Osiraq nuclear reactor, after which Israel explicitly justified its action as anticipatory self-defence. See UNSC Verbatim Record, UN Doc S/PV.2288 (19 June 1981), 79-84 ("Israel had full legal justification to exercise its inherent right of self-defence [...]"); Christine Gray, International Law and the Use of Force (2008), 115. It is notable that, in relation to the incident, Israel itself argued that the danger posed by the Iraqi reactor was imminent. See UNSC Verbatim Record, UN Doc S/PV.2288 (12 June 1981), 102 ("We [Israel] waited until the eleventh hour after the diplomatic clock had run out [...]"). States almost universally condemned the action, but, notably, most States did so on the basis that the threat to Israel was, contrary to what Israel had claimed, not imminent. See, e.g., UNSC Verbatim Record, UN Doc S/PV.2288 (19 June 1981), 28-30 (noting that while Israel may have legitimately felt threatened, there were still non-military solutions available); UNSC Verbatim Record, UN Doc S/ PV.2288 (16 June 1981), 44-7 ("Today the Israelis attack Baghdad for having a nuclear reactor centre that was described by the [...] IAEA [. . .] as 'peaceful nuclear facilities.”); UNSC Verbatim Record, UN Doc S/PV.2288 (15 June 1981), 53-6 (referring to the air raid on Iraq's capital as an "unprovoked" act of terrorism). Of course, a number of other States argued that the action was unlawful because selfdefence against a threat is unlawful per se. See UNSC Verbatim Record, UN Doc S/ PV.2283 (15 June 1981), 22 (the Soviet Union, referring to such actions as "the law of the jungle").

94 See Grimal and Sundaram, above n.1. 
33. From the breach/compliance of outer space provisions purporting to regulate the non-militarization of outer space, the intercepting State cannot, of course, be in any violation (of OST provisions) given that this is taking place on terra firma. The "carrying" State, however, may be in breach of not only CHOM, but also Article IV (which bars any State parties to the treaty from placing WMD in the Earth's orbit), and IX (if one views that those activities are not for peaceful explorative purposes) of the OST, and Article II of the PPWT (although it remains a draft), as its very action is intending to carry such material into out outer space with a view to weaponizing its space facilities. Equally, one could counter the above conclusion and suggest that a breach of CHOM may not necessarily be the case (given that $\mathrm{CHOM}$ is unclear as to the substance obligation). With regard to the "threshold" and "violation" aspects of the outer space framework as a whole, scenario 1 emphatically affirms the position that the threshold of militarization is actually quite low-in other words, a State can easily breach its obligations for non-militarization. As soon as the "carrying" State's military components effectively enter outer space, the authors view that it may well be in violation of the non-militarization principle. The "intercepting" State's action meanwhile (from a purely non-militarization of space standpoint) will clearly be in no breach for the reasons detailed above. While undoubted problems arise from jus ad bellum non-compliance by the "intercepting" State (given that the "intercepting" State's action takes place within the Earth's atmosphere), the OST and supporting instruments are not yet applicable.

\section{Scenario 2: Interception by State B against State A's satellite which is exiting Earth's atmosphere and entering outer space}

34. In this scenario, the paradigm moves one step closer towards weaponization. However, interception is perhaps too far removed in the temporal sense to justify an action of lawful self-defence- such action would, at best, fall within pre-emptive selfdefence, and therefore be considered unlawful. As regards the actions of the "carrying" State, it can be argued that they are in violation of the CHOM, Article IX of OST and Article II of PPWT (although it remains a draft). The key provisions of the scenario touches upon the following, namely, Articles III, ${ }^{95}$ IV(2), and IX ${ }^{96}$ of the 30 OST. Taken to its extreme, let us suppose the following: a liberal interpretation of Article IX would seemingly permit State A to neutralize its own satellite. ${ }^{97}$ When State A then neutralises State B's satellite that is in outer space, it will not be necessarily breach Article IX. The "threshold" of militarization remains the same of course, as in scenario 1 . However, scenario 2 underlines the fact that the mere transportation

95 Blount, above n.30; Blount, above n.46.

$96 \mathrm{Su}$, above n.64.

97 The PRC in 2007 destroyed its own satellite, and likewise the US neutralized its satellite in 2008. 
(at least by the "carrying" State) will probably breach their obligations regarding nonmilitarization. Moreover, the "launch" State, in attempting to curtail such behaviour- justified perhaps on the more remote and tenuous grounds of self-defence against a non-imminent and latent threat—will equally fall foul of non-militarization obligations.

Scenario 3: Interception against the "delivery vehiclelcargo ship" that has successfully delivered its military payload to the space station and is re-entering the Earth's atmosphere 35. While scenario three does differ from scenario 2, relatively little has changed as such; one is simply "shooting the messenger". Such action can no longer be considered in terms of self-defence and is more "reprisal like" in nature. ${ }^{98}$ Both the "carrying" State and the "intercepting" State will be in breach of international law provisions as posited in scenario 2. The "carrying" State will be in breach of CHOM, and Article IX of OST, for seeking to weaponize Outer Space, and the "intercepting" State will be in breach of Articles III, IV(2), and IX of the OST, for intercepting a vehicle which is on the point of re-entering the Earth's atmosphere without any weapons on board. Breach of non-militarization principles in this scenario is fairly selfexplanatory and the threshold here remains the same as set out in scenarios 1 and 2 .

\section{Scenario 4: A cyber-attack against a land-based command and control centre (which has kinetic consequences in space)}

36. State $\mathrm{A}$ in our scenario launches a strike (cyber) against a land-based command and control centre. The attacking State will probably be in breach of Article 2(4) of the UN Charter, but the attack itself may not necessarily run contrary to any provisions of the OST, CHOM, etc. Again, in the present scenario, it can be argued that both State A and State B have breached international law provisions as posited in scenario 2 and 3. Threshold-wise, the issue as to whether militarization has taken place is more complicated. The threshold would appear to be much higher-and in other words, there is possible doubt as to whether an action taken against a land-based command and control centre, which has resulting consequences in outer space, is directly in violation of the OST. While the consequences have taken place in space, the attack itself has been consummated on terra firma. Conceivably, this is somewhat similar to the broader issue surrounding cyber warfare in general and whether kinetic consequences are required in order for a potential violation of Article 2(4) to have occurred. Here of course, the authors use this example as an analogy. The fact that there may be spaced-based consequences as a result of a land-based cyber-attack may make it difficult to reconcile as a breach of the OST. The authors note that this still leaves the

98 Reprisals are commonly viewed as being unlawful under international law. For a useful commentary see, Shane Darcy, Retaliation and Reprisal, in: Marc Weller (ed.), The Oxford Handbook of the Use of Force in International Law (2015), 879-896. 
question as to whether interception has to occur in outer space in order for the nonmilitarization principle to have been violated.

\section{Scenario 5: Could a satellite providing GPS for both military and civilian purposes (dual} use) be in violation of key tenets of the outer space framework?

37. In this scenario, Article IV of the OST does not apply, as the satellite is not carrying a WMD. Article III of the OST could apply in extremis, but the host State would then need to justify that the satellite is there for purely non-military purposes.

38. From the above analysis, the following observations can be made. A State could lawfully have recourse to countermeasures ${ }^{99}$ (non-forceful and therefore not breaching Article 2(4) of the UN Charter) ${ }^{100}$ to prevent militarization in outer space. ${ }^{101}$ In 10 all of the above scenarios, if interception is taking place in outer space then that is also clearly militarization. When military personnel are present in outer space to carry out such peaceful activities, it will not automatically constitute weaponization/militarization of space, provided the use of such military personnel is limited to scientific or peaceful purposes following Article IV(2) of OST. In the context of a spacecraft being equipped with defensive missiles - this could potentially amount to militarization, unless one accepts the ASAT discussion under scenario 1. And finally (and solely from an entirely theoretical perspective), does Article 51 of the UN Charter trump non-militarization principles (Article 51 vs. Article IV of the OST)? In other words, could State A, as a part of a lawful invocation of self-defence, respond to a land-based armed attack by neutralising its attacker's outer-space capabilities? ${ }^{102}$ From the foregoing discussions one can argue that Article 51 must trump non-militarization principles.

99 One would also need to consider the availability of "countermeasures" or other applicable defences within the context of precluding wrongfulness such as necessity, distress or force-majeure. See Mary Ellen O'Connell, Cyber Security without Cyber War, 17 JCSL (2012), 187, 204-5. Yaroslav Radziwill, Cyber-Attacks and the Exploitable Imperfections of International Law (2015), 157.

100 Article 2(4) of the UN Charter, prohibits the inter-state threat and use of force. See, for example, Olivier Corten, The Law Against War: The Prohibition on the Use of Force in Contemporary International Law (2010), 50-197; Thomas M Franck, Recourse to Force: State Action Against Threats and Armed Attacks (2002), 11-9; and Nico Schrijver, The Ban on the Use of Force in the UN Charter, in: Marc Weller (ed.), The Oxford Handbook of the Use of Force in International Law (2015), 466.

101 The deployment of dual use objects such as navigation satellites, even if regarded as militarization of space, is not prohibited by international law.

102 A State's inherent right of self-defence fuses both customary international law and Charter law in the form of Article 51. See Green and Grimal, above n.88. See also Etezazian, above n.87. Etezazian provides the useful commentary, which will be used by the authors in the discussion. Etezazian notes: "Some writers nonetheless have expressed the view that the geographical requirement of self-defence should be 
39. It is not inconceivable that any of the above scenarios (the "carrying" State purporting to weaponize) could also constitute a threat to international peace and security, thus triggering Article 39 of the UN Charter, and allowing the UNSC to become seized of the matter. ${ }^{103}$ This, of course, is highly contingent on a much broader interpretation by the UNSC as to what may constitute a threat to international peace and security as per its remit set out in Article 24 of the UN Charter. The UNSC has historically moved away from an overly restrictive interpretation of what constitutes a threat under Article 39 of the UN Charter. ${ }^{104}$ However, given that most, if not all, of the permanent five Members of the UNSC have an "interest" in space, the recourse to veto, or a threatened veto under Article 27(3) of the UN Charter remains a highly distinct possibility. For instance, when PRC in 2007 destroyed its own satellite, fearing that it could cause potential harm on re-entry into the atmosphere, the response from States that were actively engaged in outer space activities was muted. ${ }^{105}$ The threshold concept and, perhaps more specifically here, the issue of toleration suggest some acceptance that this type of confined action by States (as one of the present authors has coined elsewhere) ${ }^{106}$ could be deemed as "tolerably unlawful" rather than "lawfully tolerable".

\section{Conclusion}

40. In conclusion, the most problematic scenario in terms of compliance with international law concerns the interception against the launch of a satellite delivering a nuclear warhead (or at the very least some form of military component). Reconciling

interpreted more flexibly, especially in the case of large-scale or repeated attacks, which threaten the very survival of the victim state". Etazazian, noting Schachter, comments: "An isolated attack on one place-say, in a disputed territorial zonewould not normally warrant a defensive action deep into the territory of the attacking state. However, the situation may change when a series of attacks in one area leads to the conclusion that defense requires a counter-attack on the source of the attack." See also Oscar Schachter, International Law in Theory and Practice (1991), $153-54$.

103 As White, (in citing Kelsen) notes, the discretion as to what constitutes a "threat to the peace" under Article 39 of the UN Charter remains a decision at the behest of the UNSC. See Nigel D. White, The Relationship Between the UN Security Council and General Assembly in Matters of International Peace and Security, in: Marc Weller (ed.), The Oxford Handbook of the Use of Force in International Law (2015), 293-313.

104 Ibid., 299.

105 Kaufman, above n. 50 .

106 See Francis Grimal, Threats of Force: International Law and Strategy (2013), Chapter VII; Francis Grimal and Graham Melling, The Protection of Nationals Abroad: Lawfulness or Toleration? A Commentary, 16 JCSL (2011), 541-554. 
actions within the framework of self-defence generally, for the reasons stated above, are both impractical and improbable: necessity and proportionality, let alone the concept of armed attack ${ }^{107}$ are difficult to satisfy. The second scenario controversially raises the issue as to the strategic desirability of interception before it is "too late" in the military sense. However, from a legal perspective, interception is perhaps too far removed in the temporal sense before lawful forceful action can take place. Scenario 3 , as noted above, offers little variance in terms of conclusion, whereas Scenario 4 would undoubtedly be deemed as both a violation of Charter norms and also a flagrant breach of space norms by the State who has chosen to station a military facility in space. While the overall analogy of a first strike against a military facility in space is undoubtedly similar to that of a strike against a terrestrial nuclear facility, the nature of space may require a recalibration when it comes to interception. In turn, this reopens the perennial debate as to whether one simply transposes existing jus ad bellum parameters to outer space, or if the situation requires more sensitive calibration.

41. This still leaves us with the opportunity to engage with the question of how one might in fact "transpose" the existing jus ad bellum regime to outer space. Certainly, from a conceptual perspective, it would be more productive to recalibrate and interpret the existing parameters to fit the "uniqueness" of outer space rather than simply to hold that the current regime is insufficient. The peculiarities, or uniqueness, of outer space as a potential battlefield require a re-appraisal of the thresholds for the cardinal prohibition of the threat or use of force in Article 2(4) and a State's lawful recourse to self-defence under both Article 51 and customary international law. Overwhelmingly, the scenarios deconstructed above suggest the somewhat perverse situation of "temporarily" militarizing outer space for the purposes of interception (albeit in potential breach of existing Conventions) so as to prevent all-out militarization of outer space.

42. The existing international law relating to the exploitation of outer space activities, through its ambiguities, tacitly allows for the incremental weaponization of outer space. Confined instances such as the "downing" of an ASAT, has, as noted previously, received muted critique from other States despite the fact that the action is in of itself a breach of the non-militarization principle. Consequently, one faces the rather paradoxical situation of having a low militarization threshold in tandem with a high toleration/"pain" threshold by other States (albeit in confined instances).

107 Article 51 of the UN Charter requires that the State exercising its inherent right of self-defence must have suffered an "armed attack". See Nicaragua Merits Case, and Case Concerning Oil Platforms, above n.88. 
This is a pre-copyedited, author-produced version of an article accepted for publication in Chinese Journal of International Law following peer review. The version of record Grimal F. and Sundaram, J. (2018), is available online at: doi:10.1093/chinesejil/jmy006. 